\title{
THE VARIATION OF CYSTOLITHS AND ITS TAXONOMIC SIGNIFICANCE IN ACANTHACEAE OF PENINSULAR MALAYSIA
}

\author{
SITI MAISARAH ZAKARIA ${ }^{1}$, CHE NURUL AINI CHE AMRI ${ }^{*}$, NORAINI TALIP ${ }^{2}$, \\ ABDUL LATIFF $^{2}$, AMIRUL AIMAN AHMAD JUHARI ${ }^{3}$, ROZILAWATI SHAHARI ${ }^{1}$, \\ NUR SHUHADA TAJUDIN ${ }^{1}$ and MOHAMAD RUZI ABDUL RAHMAN ${ }^{2}$ \\ ${ }^{1}$ Department of Plant Science, Kulliyyah of Science, International Islamic University Malaysia, \\ Jalan Sultan Ahmad Shah, 25200 Kuantan, Pahang \\ ${ }^{2}$ School of Environment and Natural Resource Sciences, Faculty of Science and Technology, \\ Universiti Kebangsaan Malaysia, 43600 Bangi, Selangor \\ ${ }^{3}$ Department of Environment, Faculty of Forestry and Environment, \\ Universiti Putra Malaysia, 43400 UPM Serdang, Selangor \\ EE-mail: chenurulainicheamri@iium.edu.my
}

Accepted 22 April 2020, Published online 31 December 2020

\begin{abstract}
The foliar anatomical studies of 41 species of Acanthaceae from Peninsular Malaysia had been carried out. This study aims to identify the morphology and distributions of cystoliths in leaf anatomy and their taxonomic values in species studied of Acanthaceae. The foliar anatomical study involved procedures such as cross-section by using sliding microtomes on the petiole, lamina, and midrib, epidermal peel, leaf clearing, and observation under a light microscope. The finding in this study showed four types of cystoliths present in all species studied except in Acanthus, Staurogyne, Thunbergia, and Avicennia. Generally, they are present in lamina, petiole, and midrib but differ in shapes and sizes. Four types of cystolith cells are either solitary with round cystoliths, solitary with elongated cystoliths with blunt extremities, solitary with elongated cystoliths with one end pointed, or solitary with a point at both ends. However, this type of cystoliths is varied even within the same species either in petiole, midrib, or lamina. In conclusion, results showed that the occurrence and variation of cystolith cells have a taxonomic significance which can be used in identification and classification either at genus or species level in Acanthaceae.
\end{abstract}

Key words: Cystolith cells, leaf anatomy, taxonomic significance, Acanthaceae

\section{INTRODUCTION}

The Acanthaceae family, which is known as a large pan-tropical family is mainly herbaceous and shrubs but some of the members are climbers or liana as in Thunbergia and Mendoncia, whilst a few species are woody plants as in Gratophyllum and Sanchezia (Metcalfe \& Chalk, 1965; Carlquist, 1988; Scotland et al., 1995; Scotland \& Vollesen, 2000). Acanthaceae family belongs to order Lamiales with at least 3000 species in some 250 genera with the center of distributions in IndoMalaysia, Africa (including Madagascar), Northern South America, Central America, and Mexico; with 35 genera are native or naturalized in Peninsular

\footnotetext{
* To whom correspondence should be addressed.
}

Malaysia (Keng, 2003). Previous research that has been done by Bremekamp (1965) divided Acanthaceae into two groups based on the presence and absence of cystoliths, monothecate anthers, and colpate pollen. Mc Dade et al. (2008) later divided Acanthaceae into four families; Acanthoideae, Andrographideae, Nelsonioideae, and Thunbergioideae. Whislt Vollesen (2008) then elevated the Tribe Ruellieae to subfamily Ruellioideae. However, new findings by Schwarzbach and Mc Dade (2002) and Borg (2008) have suggested that Avicennia has a sister relationship with Acanthaceae based on the floral characters shared between Avicennia and Thunbergioideae but it is still questionable and unclear in Acanthaceae lineages. Borg and Schonenberger (2011) also opined that possible floral or developmental 
apomorphies of Thunbergioideae and Avicennioideae. Surprisingly, Stevens (2016) in Angiosperm Phylogeny Website (APweb) later divided Acanthaceae into 4 subfamilies which are; Nelsonioideae, Acanthoideae, Thunbergioideae, and Avicennioideae.

It has been noticed that one of the major characteristics of Acanthaceae is the presence of cystoliths that are visible with the magnifying lens as rod-shaped especially in the epidermis surfaces of the leaves. Ajello (1941) has explained that cystoliths originated from Greek by which cyst is "cavity" whereby lith is "stone". In other words, cystoliths are calcium carbonate deposited in an organic matrix in specialized cells especially in roots, stems, or leaves of certain plant families. Cystoliths are also defined as a form of silicified bodies with a cellulose skeleton or occasionally not encrusted, they occur in both axis and leaf of numerous species (Metcalfe \& Chalk, 1965). It was first discovered the occurrence of cystoliths in Ficus by Meyen in 1827 and since then another number of plant families including Acanthaceae and Urticaceae been noticed to have cystoliths (Record, 1927).

The function of cystoliths was a matter of speculation as reported by Watt et al. (1987). However, he accepted that under certain conditions, cystolith like calcium oxalate crystals can function as repositories of calcium for metabolic and growth requirements. Apart, this cystolith can serve as temporary storage for calcium which later on will be remobilized during calcium starvation in plants (Smith, 1982). Apart, Bauer et al. (2011) also opined that the occurrence of minerals in plants may increase their tolerance to stresses of biotic and abiotic origin. To be surprised, the occurrence and distribution of cystoliths are valuable for the recognition of genera and species in selected families such as in Acanthaceae, Moraceae, and Urticaceae. Therefore, it was a great interest to understand and study the occurrence of minerals liked cystoliths cells.

Generally, cystoliths are found in selected vegetative parts and vary in size, shape, and color throughout the Acanthaceae family (Patil \& Patil, 2011). To be noticed, the cystoliths consisting of calcium carbonate can be found in the lithocysts. According to Mauseth (1988), the lithocysts present in the form of papillate or hair-like lithocysts and occur mostly in the epidermal layer of the leaves. Previous studies of the occurrence and distribution of cystoliths have been carried out by many taxonomists but it is still limited especially in Peninsular Malaysia. Therefore, the aim of this study to investigate the occurrence and distribution of cystoliths in all species studied so that it can be used in the classification of Acanthaceae in Peninsular Malaysia.

\section{MATERIALS AND METHODS}

This study was conducted on 41 taxa of Acanthaceae, a list of species studied is given in Table 1. Fresh specimens were collected from several forest reserve and mangrove areas in Peninsular Malaysia such as in Larut Matang, Perak, and Mersing, Johor. Three replicates of each plant species were used throughout this research. However, the replication of each plant species depends on the accessibility of that plant. Voucher specimens were deposited at Universiti Kebangsaan Malaysia Herbarium (UKMB). Fresh specimens were fixed in 3:1 AA Solutions $(70 \%$ Alcohol: 30\% Acetic Acid). Part of petioles, midribs, leaf lamina, and marginal was sectioned in a various range of thickness $(15-40 \mu \mathrm{m})$ using sliding microtomes and stained using Safranin and Alcian blue. Epidermal peels were prepared using Jeffery solution. The underside of leaf surfaces was first scraped off with a razor blade and soaked in Jeffery solution for few hours. The cleared leaf was washed and stained with Safranin. The specimens obtained from sliding microtome and epidermal peeling methods were undergone a dehydration process in a series of alcohol and mounted in Euparal. For the leaf clearing part, leaf lamina and margin were cut and soaked in Basic Fuchsin solution before been placed in an oven that set up at $60^{\circ} \mathrm{C}$ for a few days. The cleared leaf was undergone a dehydration process in a series of alcohol and mounted in Canada balsam. All slides were covered with coverslips and kept in the oven for two weeks at about $60^{\circ} \mathrm{C}$ for drying purposes. Anatomical images were captured using a video (3CCD) camera attached to a Leitz Diaplan microscope using Cell^B software. Suitable modifications in terms of fixation and embedding followed the method by Johansen (1940) and Saas (1958).

\section{RESULTS AND DISCUSSION}

For convenience purposes, the following structures of cystoliths have been divided into recognizable types in Table 2, which are illustrated by drawings to avoid lengthy and complex descriptions. Variations in cystolith cell shapes are characters that can be used as an additional feature in the classification of plants, either at the genus or species level of Acanthaceae. Besides, the following Table 3 is a summary of the distribution of cystolith in species studied based upon their types. 
Table 1. List of specimens of Acanthaceae species studied

\begin{tabular}{|c|c|c|c|}
\hline Species & Locality & Collector & Code and Date \\
\hline $\begin{array}{l}\text { Andrographis paniculata } \\
\text { (Burm. f.) Wall. ex Nees }\end{array}$ & Johor, Mersing & $\begin{array}{l}\text { Nurul-Aini C.A.C., Sani, } \\
\text { M. \& Nik Norafida, N.A. }\end{array}$ & $\begin{array}{l}\text { CNA } 32 \text { (UKMB) } \\
30.5 .2012\end{array}$ \\
\hline $\begin{array}{l}\text { Asystasia gangetica (L.) T. } \\
\text { Anderson }\end{array}$ & $\begin{array}{l}\text { Terengganu, Pantai Batu } \\
\text { Burok }\end{array}$ & Nurul-Aini C.A.C. & $\begin{array}{l}\text { CNA } 129 \text { (UKMB) } \\
10.4 .2014\end{array}$ \\
\hline $\begin{array}{l}\text { Asystasia gangetica T. } \\
\text { Anderson subsp. micrantha } \\
\text { (Nees) Ensermu }\end{array}$ & Selangor, Bangi & $\begin{array}{l}\text { Nurul-Aini, C.A.C. and } \\
\text { Ruzi, R.A. }\end{array}$ & $\begin{array}{l}\text { CNA } 2 \text { (UKMB) } \\
9.5 .2012\end{array}$ \\
\hline Barleria prionitis L. & Selangor, Serdang & $\begin{array}{l}\text { Nurul-Aini, C.A.C. and } \\
\text { Ruzi, R.A. }\end{array}$ & $\begin{array}{l}\text { CNA } 92 \text { (UKMB) } \\
19.9 .2012\end{array}$ \\
\hline $\begin{array}{l}\text { Blechum pyramidatum (Lam.) } \\
\text { Urb. }\end{array}$ & Selangor, Bangi & $\begin{array}{l}\text { Nurul-Aini, C.A.C. and } \\
\text { Ruzi, R.A. }\end{array}$ & $\begin{array}{l}\text { CNA } 128 \text { (UKMB) } \\
1.4 .2014\end{array}$ \\
\hline $\begin{array}{l}\text { Chroesthes longifolia (Wight) } \\
\text { B. Hansen }\end{array}$ & Selangor, Bangi & $\begin{array}{l}\text { Nurul-Aini, C.A.C. and } \\
\text { Ruzi, R.A. }\end{array}$ & $\begin{array}{l}\text { CNA } 3 \text { (UKMB) } \\
9.5 .2012\end{array}$ \\
\hline Filetia bracteosa C.B. Clarke & Perak, Taiping & Ruzi, R.A. & $\begin{array}{l}\text { CNA } 132 \text { (UKMB) } \\
21.10 .2014\end{array}$ \\
\hline $\begin{array}{l}\text { Filetia scortechinii C. B. } \\
\text { Clarke }\end{array}$ & $\begin{array}{l}\text { Selangor, Rawang, } \\
\text { Hutan Rimba Kanching }\end{array}$ & $\begin{array}{l}\text { Nurul-Aini, C.A.C. and } \\
\text { Ruzi, R.A. }\end{array}$ & $\begin{array}{l}\text { CNA } 18 \text { (UKMB) } \\
22.5 .2012\end{array}$ \\
\hline $\begin{array}{l}\text { Hemigraphis alternata (Burm. } \\
\text { f.) T. Anderson }\end{array}$ & Selangor, Serdang & $\begin{array}{l}\text { Nurul-Aini, C.A.C. and } \\
\text { Ruzi, R.A. }\end{array}$ & $\begin{array}{l}\text { CNA } 93 \text { (UKMB) } \\
19.2 .2012\end{array}$ \\
\hline $\begin{array}{l}\text { Hemigraphis reptans (G. } \\
\text { Forst.) T. Anderson ex Hemsl. }\end{array}$ & Selangor, Bangi & $\begin{array}{l}\text { Nurul-Aini, C.A.C. and } \\
\text { Ruzi, R.A. }\end{array}$ & $\begin{array}{l}\text { CNA } 38 \text { (UKMB) } \\
30.5 .2012\end{array}$ \\
\hline $\begin{array}{l}\text { Hygrophila pusilla Blume ex } \\
\text { Steud. }\end{array}$ & $\begin{array}{l}\text { Perak, Tapah, Hutan } \\
\text { Lipur Lata Kinjang }\end{array}$ & Aiman, M.A. \& Ruzi, R.A. & $\begin{array}{l}\text { MAA } 67(\text { UKMB) } \\
8.3 .2014\end{array}$ \\
\hline Justicia betonica L. & Selangor, Bangi & $\begin{array}{l}\text { Nurul-Aini, C.A.C. and } \\
\text { Ruzi, R.A. }\end{array}$ & $\begin{array}{l}\text { CNA } 6 \text { (UKMB) } \\
9.5 .2012\end{array}$ \\
\hline Justicia carnea Lindl. & Pahang, Bukit Fraser & Aiman, M.A. \& Ruzi, R.A. & $\begin{array}{l}\text { MAA } 22 \text { (UKMB) } \\
22.5 .2013\end{array}$ \\
\hline Justicia comata (L.) Lam. & $\begin{array}{l}\text { Negeri Sembilan, Kuala } \\
\text { Pilah, Kampung } \\
\text { Gementir Baru }\end{array}$ & Aiman, M.A. \& Ruzi, R.A. & $\begin{array}{l}\text { MAA } 45 \text { (UKMB) } \\
19.6 .2013\end{array}$ \\
\hline Justicia gendarussa Burm.f. & $\begin{array}{l}\text { Perak, Tapah, Hutan } \\
\text { Lipur Kuala Who }\end{array}$ & Aiman, M.A. \& Ruzi, R.A. & $\begin{array}{l}\text { MAA } 61(\text { UKMB) } \\
7.3 .2014\end{array}$ \\
\hline Justicia procumbens L. & $\begin{array}{l}\text { Perak, Tapah, Hutan } \\
\text { Lipur Kuala Who }\end{array}$ & Aiman, M.A. \& Ruzi, R.A. & $\begin{array}{l}\text { MAA } 63 \text { (UKMB) } \\
7.3 .2014\end{array}$ \\
\hline Justicia ptychostoma Nees & $\begin{array}{l}\text { Terengganu, Besut, } \\
\text { Hutan Lipur Lata Belatan }\end{array}$ & $\begin{array}{l}\text { Nurul-Aini, C.A.C. and } \\
\text { Ruzi, R.A. }\end{array}$ & $\begin{array}{l}\text { CNA } 76 \text { (UKMB) } \\
11.7 .2012\end{array}$ \\
\hline $\begin{array}{l}\text { Peristrophe acuminata Nees } \\
\text { var. acuminata }\end{array}$ & Selangor, Bangi, & $\begin{array}{l}\text { Nurul-Aini C.A.C. \& Ruzi, } \\
\text { R.A. }\end{array}$ & $\begin{array}{l}\text { CNA } 7 \text { (UKMB) } \\
9.5 .2012\end{array}$ \\
\hline Peristrophe bivalvis Merr. & Selangor, Gombak & Ruzi, R.A. & $\begin{array}{l}\text { CNA } 97 \text { (UKMB) } \\
5.11 .2012\end{array}$ \\
\hline $\begin{array}{l}\text { Pseuderanthemum } \\
\text { carruthersii (Seem.) } \\
\text { Guillaumin }\end{array}$ & Selangor, Bangi & $\begin{array}{l}\text { Nurul-Aini, C.A.C. and } \\
\text { Ruzi, R.A. }\end{array}$ & $\begin{array}{l}\text { CNA } 117 \text { (UKMB) } \\
29.11 .2012\end{array}$ \\
\hline $\begin{array}{l}\text { Pseuderanthemum } \\
\text { crenulatum Radlk. }\end{array}$ & Selangor, Bangi & $\begin{array}{l}\text { Nurul-Aini, C.A.C. and } \\
\text { Ruzi, R.A. }\end{array}$ & $\begin{array}{l}\text { CNA } 116 \text { (UKMB) } \\
29.11 .2012\end{array}$ \\
\hline Rhinacanthus nasutus Kuntze & $\begin{array}{l}\text { Negeri Sembilan, Nilai, } \\
\text { Taman Semarak }\end{array}$ & $\begin{array}{l}\text { Nurul-Aini, C.A.C. and } \\
\text { Ruzi, R.A. }\end{array}$ & $\begin{array}{l}\text { CNA } 116 \text { (UKMB) } \\
29.11 .2012\end{array}$ \\
\hline Ruellia repens $\mathrm{L}$. & Pahang, Tasik Chini & $\begin{array}{l}\text { Nurul-Aini, C.A.C., Aiman, } \\
\text { M.A. \& Ruzi, R.A. }\end{array}$ & $\begin{array}{l}\text { CNA } 101 \text { (UKMB) } \\
7.11 .2012\end{array}$ \\
\hline Ruellia simplex C. Wright & Pahang, Tasik Chini & $\begin{array}{l}\text { Nurul-Aini, C.A.C., Aiman, } \\
\text { M.A. \& Ruzi, R.A. }\end{array}$ & $\begin{array}{l}\text { CNA } 106 \text { (UKMB) } \\
7.11 .2012\end{array}$ \\
\hline Ruellia tuberosa L. & Selangor, Sepang & Sani, M. & $\begin{array}{l}\text { SM } 2266(\text { UKMB) } \\
26.6 .2012\end{array}$ \\
\hline Sanchezia speciosa Leonard & Pahang, Bukit Fraser & Aiman, M.A. \& Ruzi, R.A. & $\begin{array}{l}\text { MAA } 19 \text { (UKMB) } \\
22.5 .2013\end{array}$ \\
\hline $\begin{array}{l}\text { Strobilanthes crispa T. } \\
\text { Anderson }\end{array}$ & $\begin{array}{l}\text { Terengganu, Besut, } \\
\text { Hutan Lipur Lata } \\
\text { Tembakah }\end{array}$ & $\begin{array}{l}\text { Nurul-Aini, C.A.C. \& Ruzi, } \\
\text { R.A. }\end{array}$ & $\begin{array}{l}\text { CNA } 84 \text { (UKMB) } \\
11.7 .2012\end{array}$ \\
\hline
\end{tabular}


Table 2. Type of cystolith cells in species studied

\begin{tabular}{|c|l|c|c|}
\hline Type & Cystolith description & $\begin{array}{l}\text { Solitary cystoliths } \\
\text { with rounded - shaped }\end{array}$ \\
\hline Type 1 & $\begin{array}{l}\text { Type 2 } \\
\text { cystoliths with }\end{array}$ & $\begin{array}{l}\text { Solitary elongated } \\
\text { blunt }\end{array}$ \\
\hline Type 3 & $\begin{array}{l}\text { Solitary elongated } \\
\text { eystoliths with one } \\
\text { end pointed }\end{array}$ \\
\hline Type 4 & $\begin{array}{l}\text { Solitary elongated } \\
\text { cystoliths with end } \\
\text { pointed for both side }\end{array}$ \\
\hline
\end{tabular}

Table 3. Distribution of cystolith cells in species studied based upon their types

\begin{tabular}{|c|c|c|c|c|}
\hline \multirow{2}{*}{ Species / type of cystolith cells } & \multicolumn{4}{|c|}{ Type of cystolith cells } \\
\hline & Type 1 & Type 2 & Type 3 & Type 4 \\
\hline Andrographis paniculata & + & + & - & - \\
\hline Asystasia gangetica & + & + & - & - \\
\hline Asystasia gangetica subsp. micrantha & + & - & - & - \\
\hline Barleria prionitis & + & - & - & - \\
\hline Blechum pyramidatum & + & - & + & - \\
\hline Chroesthes longifolia & + & - & + & - \\
\hline Filetia bracteosa & + & - & + & - \\
\hline Filetia scortechinii & + & - & + & - \\
\hline Hemigraphis alternata & + & - & - & + \\
\hline Hemigraphis reptans & + & + & + & - \\
\hline Hemigraphis glaucescens & + & - & - & + \\
\hline Hygrophila pusilla & + & - & - & - \\
\hline Justicia betonica & + & - & - & - \\
\hline Justicia carnea & + & - & - & - \\
\hline Justicia comata & + & - & - & - \\
\hline Justicia gendarussa & + & + & - & - \\
\hline Justicia procumbens & + & - & - & + \\
\hline Justicia ptychostoma & + & - & + & - \\
\hline Peristrophe acuminata var. acuminata & + & - & - & + \\
\hline Peristrophe bivalvis & + & + & - & + \\
\hline Pseuderanthemum carruthersii & + & + & - & + \\
\hline Pseuderanthemum crenulatum & + & + & - & - \\
\hline Rhinacanthus nasutus & + & - & - & - \\
\hline Ruellia repens & + & - & - & - \\
\hline Ruellia simplex & + & - & - & - \\
\hline Ruellia tuberosa & + & - & + & - \\
\hline Sanchezia speciosa & + & - & - & + \\
\hline Strobilanthes crispa & + & - & - & - \\
\hline
\end{tabular}


The occurrence of cystoliths can be observed by their various shapes and types. According to Balkwill and Norris (1985), four main cystolith shapes have been recognized based upon six taxa studied belongs to the genus Hypoestes of Acanthaceae by which 'boomerang-shaped' being the most common shape. The present study hence provided four main types of cystoliths cells based upon 41 taxa studied in Acanthaceae. Four types of cystoliths as shown in Table 2 including Type 1 (solitary cystolith with rounded-shaped), Type 2 (solitary cystolith with blunt-end), Type 3 (solitary cystolith elongated with one end pointed), and Type 4 (solitary cystolith elongated with end pointed both). It was discovered that the most common type that occurred was Type 1 cystolith cells. Besides, it was noticed that three types of cystoliths cells occurred only in three species which are $H$. reptans (Type 1, 2 \& 3), P. bivalvis (Type 1, 2 \& 4), and $P$. carruthersii (Type 1, $2 \& 4$ ) whereby only Type 1 cystolith occurred in A. gangetica subsp. micrantha, B. prionitis, H. pusilla, J. betonica, J. carnea, J. comata, $R$. nasutus, $R$. repens, $R$. simplex, and $S$. crispa. The results hence prove that various types of cystolith themselves can be considered as an additional feature in the taxonomic study. Mauseth (1988) reported that the occurrence of cystolith can be found in various parts of plants especially in the leaves which also including xylem and phloem rays. The nature and distribution of cystolith are valuable and useful to delimit plant taxa (Metcalfe \& Chalk, 1950). This present study therefore provided data on the distribution of cystolith in 41 taxa of Acanthaceae in Peninsular Malaysia based upon their occurrence in epidermal cells and parenchyma cortex of leaf which is shown in Table 4 below.

A previous study by Ummu-Hani and Noraini (2013) has reported the classification of 15 taxa in Ficus according to the position of their cystoliths. Generally, cystoliths in Ficus occurred in the cells of multiple epidermises (Foster, 1949; Esau, 1965). From the study, three groups of cystoliths were categorized accordingly which Group 1 with cystoliths adjacent to the adaxial epidermis layer, Group 2 with cystoliths adjacent to the abaxial epidermis layer, and Group 3 with cystoliths present in both adaxial and abaxial epidermis layer. The

Table 4. Distribution of cystoliths in species studied based upon their position

\begin{tabular}{|c|c|c|c|c|c|c|}
\hline \multirow{2}{*}{ Species / distribution of cystolith } & \multicolumn{3}{|c|}{ Epidermis } & \multicolumn{3}{|c|}{ Parenchyma cortex } \\
\hline & Petiole & Midrib & Lamina & Petiole & Midrib & Lamina \\
\hline Andrographis paniculata & + & + & - & - & - & - \\
\hline Asystasia gangetica & + & + & - & - & - & - \\
\hline Asystasia gangetica subsp. micrantha & - & + & - & - & - & - \\
\hline Barleria prionitis & + & + & - & - & - & - \\
\hline Blechum pyramidatum & + & + & - & + & + & - \\
\hline Chroesthes longifolia & + & + & - & - & - & - \\
\hline Filetia bracteosa & + & + & - & + & + & - \\
\hline Filetia scortechinii & + & + & - & + & + & - \\
\hline Hemigraphis alternata & + & + & - & + & + & - \\
\hline Hemigraphis reptans & + & + & - & + & + & - \\
\hline Hemigraphis glaucescens & + & + & + & - & - & - \\
\hline Hygrophila pusilla & + & + & - & - & - & - \\
\hline Justicia betonica & + & + & - & - & - & - \\
\hline Justicia carnea & + & + & - & - & - & - \\
\hline Justicia comata & + & + & - & - & - & - \\
\hline Justicia gendarussa & + & + & - & - & - & - \\
\hline Justicia procumbens & + & + & + & - & - & - \\
\hline Justicia ptychostoma & + & + & + & - & - & - \\
\hline Peristrophe acuminata var. acuminata & + & + & - & - & - & - \\
\hline Peristrophe bivalvis & - & + & + & - & + & - \\
\hline Pseuderanthemum carruthersii & + & + & + & + & - & + \\
\hline Pseuderanthemum crenulatum & + & + & + & - & - & + \\
\hline Rhinacanthus nasutus & + & + & + & - & - & - \\
\hline Ruellia repens & + & + & + & - & - & - \\
\hline Ruellia simplex & + & + & + & - & - & - \\
\hline Ruellia tuberosa & + & + & - & - & - & - \\
\hline Sanchezia speciosa & + & + & + & - & - & - \\
\hline Strobilanthes crispa & + & + & + & - & - & - \\
\hline
\end{tabular}


present study thereby reported on the occurrence of cystoliths based upon their position in epidermal cells and parenchyma cortex. From the observation, $P$. carruthersii showed the most abundance occurrence of cystoliths either in the epidermis or parenchyma cortex whereby $A$. gangetica subsp. micrantha had the least occurrence of cystoliths by which cystoliths can only be found in the epidermis of the midrib part. Furthermore, the existence of cystoliths in the parenchyma cortex of lamina parts can be only observed on both species from Pseuderanthemum thus might give a systematic value for them. Pierantoni et al. (2018) even mentioned that deposition of cystoliths can be in the upper and lower epidermis but some cases might extend into the mesophyll part hence supported the occurrence of cystoliths in the parenchyma cortex of some Acanthaceae species. It was also observed that the absence of cystoliths occurred in 13 taxa out of 41 taxa in Acanthaceae from genera of Acanthus, Avicennia, Staurogyne, and Thunbergia, thus recognized the significance of cystoliths in the identification and classification of Acanthaceae species. This present study is well supported by Heywood et al. (2007) which also mentioned the cystoliths absent in the vegetative parts of subfamilies Nelsonioideae and Thunbergioideae as well as in the tribe of Acanthae. Moreover, findings by Noor-Syaheera et al. (2015) have also revealed the absence of cystolith in the genus Avicennia.

\section{CONCLUSION}

Results of the foliar study revealed several interesting features with some characters considerable to have taxonomic significance. Finding from this study showed four types of cystoliths present in all species studied except in Acanthus, Avicennia, Staurogyne, and Thunbergia. The presence of only Type 1 cystolith in A. gangetica subsp. micrantha, B. prionitis, H. pusilla, J. betonica, J. carnea, J. comata, R. nasutus, R. repens, $R$. simplex, and $S$. crispa may be characteristics of them. Furthermore, three species were noticed to have the most various cystoliths types which referred to $H$. reptans (Type 1, $2 \& 3$ ), P. bivalvis (Type 1, 2 $\& 4$ ), and P. carruthersii (Type 1, $2 \& 4$ ). Besides, the most abundance occurrence of cystoliths can be seen in $P$. carruthersii by which occurred in all epidermis parts and two out of three parts in the parenchyma cortex, so that it may characterize the taxa. Also, A. gangetica subsp. micrantha had the least occurrence of cystoliths by which the only Type 1 cystoliths can be found in the epidermis of the midrib part. The occurrence of cystoliths in the parenchyma cortex of the lamina part can be only seen in genus Pseuderanthemum; $P$. carruthersii and
$P$. crenulatum, so that it might serve as a systematic character for them. However, it is suggested that future investigations may be focused on the anatomical location and distribution of cystolith cells. In conclusion, results from the present study showed that the occurrence and variation of cystolith cells have a taxonomic significance which can be used in classification and identification either at genus or species level of Acanthaceae.

\section{ACKNOWLEDGEMENTS}

The authors wish to thank the Herbarium of Universiti Kebangsaan Malaysia, Bangi for providing informative data on the Acanthaceae family in Peninsular Malaysia. Special thanks are dedicated to FRGS/1/2019/STG03/UIAM/03/2 for the funding of this research.

\section{REFERENCES}

Ajello, L. 1941. Cytology and cellular interrelations of cystolith formation in Ficus elastic. American Journal of Botany, 28(7): 589-594.

Balkwill, K. \& Norris, F.G. 1985. Taxonomic studies in the Acanthaceae; the genus Hypoestes in southern Africa. Southern Africa Journal of Botanical, 51: 133-144.

Bauer, P., Elbaum, R. \& Weiss, I.M. 2011. Calcium and silicon mineralization in land plants: Transport, structure and function. Plant Science, 180: 746-756.

Borg, A.J. 2008. Molecular phylogenetics and morphological evolution of Thunbergioideae (Acanthaceae). Taxon, 57(3): 811-822.

Borg, A.J. \& Schonenberger, J. 2011. Comparative Floral Development and Structure of the Black Mangrove Genus Avicennia L. and Related Taxa in the Acanthaceae. International Journal of Plant Sciences, 172(3): 330-344.

Bremekamp, C.E.B. 1965. Delimitation and subdivision of the Acanthaceae. Bulletin of the Botanical Survey of India, 7: 21-30.

Carlquist, S. 1988. Wood Anatomy of Acanthaceae: A Survey. Journal of Systematic and Evolutionary Botany, 12(1): 201-227.

Esau, K. 1965. Plant Anatomy. John Wiley and Sons, Inc., New York.

Foster, A.S. 1949. Practical Plant Anatomy. D. Van Nostrand Co., New York.

Johansen, D.A. (1940). Plant Microtechnique. McGraw-Hill, New York.

Heywood, V.H., Brummitt, R.K., Culham, A. \& Seberg, O. 2007. Flowering Plants Families of The World. Firefly Books, Canada. 23-24 pp. 
Keng, H. 2003. Orders and Families of Malayan Seed Plants. Singapore University Press, Singapore. 291-293 pp.

Mauseth, J.D. 1988. Plant Anatomy. Benjamin, Cummings, California.

Metcalfe, C.R. \& Chalk, L. 1950. Anatomy of The Dicotyledons. Clarendron Press, Oxford.

Metcalfe, C.R. \& Chalk, L. 1965. Anatomy of The Dicotyledons. Clarendon Press, Oxford.

Noor-Syaheera, M.Y., Noraini, T., Radhiah, A.K. \& Nurul-Aini, C.A.C. 2015. Leaf anatomical characteristics of Avicennia L. and some selected taxa in Acanthaceae. Malayan Nature Journal, 67(1): 81-94.

Patil, A.M. \& Patil, D.A. 2011. Occurrence and significance of cystoliths in Acanthaceae. Current Botany, 2(4): 1-5.

Pierantoni, M., Tenne, R., Rephael, B., Brumfeld, V., Cateren, A.V., Kupczik, K., Oron, D., Addadi, L. \& Weiner, S. 2018. Mineral deposits in Ficus leaves: Morphologies and locations in relation to function. Plant Physiology, 176: 1751-1763.

Record, S.J. 1927. Occurrence of calcium carbonate deposits in woods. Tropical Woods, 12: 22-26.
Saas, J.E. 1958. Botanical Microtechnique. 3rd Edition. Iowa State University, Ames.

Scotland, R.W., Sweere, J.A., Reeve, P.A. \& Olmstead, R.G. 1995. Higher level systematics of Acanthaceae determined by chloroplast DNA sequences. American Journal of Botany, 82: 266-275.

Scotland, R.W. \& Vollesen. K. 2000. Classification of Acanthaceae. Royal Botanic Gardens, Kew.

Smith, D.L. 1982. Calcium Oxalate and Carbonate Deposits in Plant Cells. CRC Press, Florida.

Stevens, P.F. 2016. angiosperm phylogeny website [WWW Document]. URL http://www.mobot.org/ MOBOT/research/APweb/ (accessed 4.3.2020).

Ummu-Hani, B. \& Noraini, T. 2013. The structure of cystoliths in selected taxa of the genus Ficus L. (Moraceae) in Peninsular Malaysia. AIP Conference Proceedings, 1571: 372-376.

Vollesen, K. 2008. Flora of Tropical East Africa: Acanthaceae. Royal Botanic Gardens, Kew.

Watt, W.M., Morrell, C.K. \& Smith, D.L. 1987. Cystolith development and structure in Pilea cadierei (Urticaceae). Annals of Botany, 60: 7184. 
